\title{
Ethical Dispute Control in Islamic Banking Relationship
}

\author{
Idris Yahaya Adamu ${ }^{1}$, Ahmad Khilmy bin Abdul Rahim ${ }^{2}$ \& \\ Abu Bakar Hamed ${ }^{3}$ \\ ${ }^{I}$ PhD Student of Islamic Business School, Universiti Utara Malaysia, Sintok 06010, Malaysia. \\ ${ }^{2}$ Senior Lecturer, Islamic Business School, Universiti Utara Malaysia, Sintok 06010, Malaysia. \\ ${ }^{3}$ Assoc. Professor, Islamic Business School, Universiti Utara Malaysia, Sintok 06010, Malaysia.
}

\begin{abstract}
This paper examines application of ethical practice in conflict management process in Islamic banking relationship. The paper used interpretive qualitative research, based on current practice of Jaiz Islamic bank in Nigeria. Data were gathered from Jaiz Islamic bank staff, through semi-structured interview. The findings show that, Jaiz Islamic bank managers uses Sulh (conciliation and compromise) more than Mushawarah (consensus building) approach, once disagreements occur. If conflict escalates, they preferably employ non-binding arbitration process using experts like Fatawal-mufti and or CBN than arbiter judge (court annexed). Managers expresses their opposition to any form of court litigation, rather, they prefer out of court settlement to settle dispute, due to resultant effect of court litigation on business relationship continuity. Jaiz Islamic bankers therefore, are found to be innovative in conflict management in all customer related issues. The study contributes to literature of dispute control by effectively resolving dispute issues at less cost.
\end{abstract}

Keywords: Dispute control, conciliation, mediation, arbitration, litigation, Islamic banking.

\section{Introduction}

Islamic banking relationship is considered as an act of Ibadah (worship to Allah), provided it is done ethically (Al-Jabali, 2006). Banking relationship is supposed to be joyful and unending mutual relationship, which may likely involve satisfaction of various demands for benefits. However, in any social relationship, one may not rule out the possibility disagreement with client, which causes feeling of unfair treatment, resulting to disputes. Dispute, if not controlled may lead to litigation, therefore, when dispute occur, one may likely pinpoint its cause, but no one knows when it may end or the extent of damage it may cause the parties involved or their business relationship (Willson, 2015). In this study, dispute management is considered as a process of taking care of any action or situation that may eventually lead to one party involved in business relationship feels aggrieved.

The impact of effective management of dispute is to achieve benefits (Maslahah), prevent hardship (Mafsadah), avoid harm (Darar) as well as protection of wealth, which are core objectives of Shari'ah. Meanwhile, Sadd al-zarai is a fundamental shari'ah concept of avoiding conflict (Sajoo, 2014).

\subsection{Problem Statement}

In business process, a small misunderstanding may lead to disputes and dispute if not controlled, may lead to arbitration or even litigation Zahraa, \& Hak, (2006). Litigation whether successfully or unsuccessfully resolved, is likely to affect continuation of business relationship (Kerwin, Jordan and Turner, 2015). There is also higher expectation of ethical practice in Islamic banks than in conventional banks (Lukonga, 2015). For instance, it is the unethical treatment of charging interest in conventional banks, and their indifference on profits or losses of their borrowing client that forces the borrowing client to justify repayment default (Loo, 2010) and consider the banks treatment as unethical. It is also unknown, how staff of Jaiz Islamic bank sees the issue of ethical practice, and its application to dispute management. It is as well disturbing that, in most Muslim countries, it is conventional institutions that are involved in arbitration, and litigation of Islamic financing issues (Oseni, 2015). Other studies like that of Oseni, Adeyemi and Mohamed Zain, (2015); Oseni and Ahmad, (2015) and Oseni, (2015), focused on dispute resolution in Islamic finance contracts. But, did not consider the role of ethical practice of Jaiz bank.

\subsection{Objectives of the study}

The paper aims at identifying how Jaiz Islamic bank control dispute through the following:

1. Intervention and deliberation by bank's management through Sulh (conciliation and compromise) between the bank and customer.

2. Use of Mushawarah (consensus building) between Shari'ah board and either friends, relatives, or referees of the customer to mediate between the bank and customer 
3. Invitation of third party experts, like CBN or CPC and Fatwa al-mufti (Shari'ah experts) for arbitration (non-binding), to control dispute.

4. Involvement of court litigation to resolve dispute between Jaiz bank and its client

The study serves as a mind opener to clients in understanding most appropriate ways of seeking redress when aggrieved and identify cost effective means of resolving dispute, and for Jaiz bank be innovative in protecting relationship, in compliance to shari'ah objective.

\subsection{Islamic dispute control}

\section{Literature Review}

It is obvious that in any form of interaction between two or more persons, conflict of interest or misunderstanding of one another may likely arise from time to time. Dispute is the consequence of circumstances created by series of events, which involves peoples' attitude and human emotions. In the event of any problem or misunderstanding between Muslims, it is expected that they remember the following verse as Allah (SWT) said:

"And obey Allah and His Messenger, and do not dispute (with one another) lest you lose courage and your strength depart, and be patient. Surely, Allah is with those who are As-Sabirin (the patient ones, etc.)".

(Qur'an Al-Anfali 8:46)

In another verse, to call the attention of Muslims unto the teachings of Prophet (SAW) whenever there is a dispute between them, Allah (SWT) said: "But no, by your Lord, they can have no Faith, until they make you (O Muhammad SAW) judge in all disputes between them, and find in themselves no resistance against your decisions, and accept (them) with full submission".

(Qur'an Nisa'i 4: 65)

With the above verse, any misunderstanding among Muslims is expected to be ironed out using the teachings of the Qur'an and Sunnah. Meanwhile, the best way Muslims can resolve misunderstandings in Islamic perspective is through reconciliations. Reconciliation is a mutual and informal process by which the parties involved communicate and try to achieve an outcome that can satisfy both parties using some set of principles Craver (2015). Negotiation is widely used method of reconciliation in most fields such as business transactions to resolve issues between conflicting interests. In this case therefore, the outcome must be within the boundaries of Islamic Shari'ah principles. If on the reconciliatory process, the issue escalates, then let the case be referred to Islamic Shari'ah board to make peace between the parties, as Allah (SWT) said:

"And if two parties or groups among the believers fall to fighting, then make peace between them both, but if one of them rebels against the other, then fight you (all) against the one that which rebels till it complies with the Command of Allah; then if it complies, then make reconciliation between them justly, and be equitable. Verily! Allah loves those who are equitable". "The believers are nothing else than brothers (in Islamic religion). So, make reconciliation between your brothers, and fear Allah, that you may receive mercy".

(Qur'an Hujura'at 49: 9 and 10)

Possibility of conflict cannot be ruled out in Islamic banking practice either. On the process of Islamic banking transaction, dispute may likely arise if either of the parties tries to manipulate a process of the transaction. This is for instance, commonly possible in the case of deferred payment sales that are debt based transactions like Bai'-Bithaman-Ajil, Murabaha and bai' al-inah. Nevertheless, the practice of these modes of transactions might likely create conflict if one party perceived the other as enhancing and perfecting an intentional deception in its implementation (Shamsudin, Salamon \& Abu-Hussin 2014).

Likewise dispute on rights and privileges of the parties may likely arise. Lukonga (2015) when considering the impact of financial literacy and consumer protection, he acknowledged the role of Shari'ah in consumer protection, he observed that unless the Islamic financial service providers are guided by Shari'ah principles, particularly in considering the financially illiterate consumers' rights and privileges, disputes may arise and can affect business relationship. Disputes he added, may lead to litigations if proper reconciliatory mechanisms are not proactively put in place. Although, Disputing business partners normally prefer to resolve their disagreements through negotiations, but subsequent interactions may likely fail due to the extreme emotional issues it may result (Craver 2015).

\subsection{Dispute control process}

The art of controlling dispute requires an innovative process (Thompson, Vorster \&Groton, 2000). Brewer, (2007) identified conventional processes of controlling dispute through mediation, while Fenn, Lowe, and Speck (1997); and Gerber, 2007) deliberate on dispute resolution through mediation, and arbitration in conventional institutions. In Islam, there are various ways to control dispute, as identified from Fiqh books of the prominent Islamic scholars (al-Duri, 2002; al-Jabali, 2006; al-Khassaf, 1978; Haidar, 1925; Rashid, 2004; Sambo \& Kadouf, 2014). The major contribution of this study is linking the two concepts; Islamic ethics and dispute control as discussed in the Table 2.1 below. 
Table 2.1: Proposed categorisation of dispute management process

\begin{tabular}{|c|c|c|c|}
\hline $\begin{array}{ll}\text { Stage } \\
\text { dispute }\end{array}$ & $\begin{array}{l}\text { Corrective } \\
\text { measure }\end{array}$ & Intervention mechanism & Fiqh books' mechanism \\
\hline \multirow[t]{3}{*}{$\begin{array}{l}\text { Dispute } \\
\text { control }\end{array}$} & \multirow[t]{2}{*}{ Mediation } & $\begin{array}{l}\text { Intervention and deliberation by bank's } \\
\text { management }\end{array}$ & Mushawarah (consensus building) \\
\hline & & $\begin{array}{l}\text { Shari'ah board and either friends, relatives, } \\
\text { guarantors, or referees of the customer }\end{array}$ & Sulh (conciliation and compromise) \\
\hline & $\begin{array}{l}\text { Arbitration } \\
\text { (non-binding) }\end{array}$ & $\begin{array}{l}\text { Expert's determination } \\
\text { like CBN and CPC }\end{array}$ & $\begin{array}{l}\text { Fatwa al-mufti (assessment by } \\
\text { experts) }\end{array}$ \\
\hline $\begin{array}{l}\text { Dispute } \\
\text { resolution }\end{array}$ & $\begin{array}{l}\text { Court } \\
\text { litigation }\end{array}$ & Litigation by industrial or civil court & \\
\hline
\end{tabular}

\subsubsection{Dispute control through Sulh and Mushawarah}

It is not surprising if dispute arise during business, but how parties decide to take care of the situation is the issue of concern and attracting attention in the field of management. Dispute can be controlled with mediation through purposeful intervention and deliberations by bank's management or shari'ah board (Hoffman, 2015). Sulh is a conciliation process to mediate between disagreeing parties while Mushawarah is to ensure consensus building in disagreed situations, they are good in dispute control (Oseni, 2015).

In dispute control, arbiter may come in to protect the interest of both parties or alternatively, one party may compromise (Abdul Hak \& Khan, 2013). Although, the process of dispute control through mediation does not consume money and time, but, there is chances of one party feeling unfairly treated after mediation process. Thus, affecting emotions of the unsatisfied part in continuing business (Oseni, 2012). Lande, \& Benner, (2016) identified that "planned early dispute resolution (PEDR)" is a good dispute control process due to its advantage of dealing with minor conflicts before they escalate to serious disputes.

\subsubsection{Dispute resolution by fatawa al-mufti,}

Involving consumer protection department (CPD) in Central bank of Nigeria $(\mathrm{CBN})$ is one of the fundamental pillars of dispute control (Bello, Suleiman, \& Danjuma, 2012), in any case, mediator is expected to observe neutrality and display expertise on the subject matter. Despite its limited enforceability, the process is cost effective, if parties consent to its outcome (Sturner, 2015), lack of consent or understanding on mediation process or its outcome by any of the parties tends to invalidate its enforceability and hence leads to litigation.

Arbitration which is non-binding is a better alternative to court litigation (Szali, 2013), if experts in the field of Islamic finance can determined the case. To ensure fair hearing, there must be a balance in power of negotiations between a bank and its customer on dispute arbitration process and in acceptance or otherwise of the arbitration's outcome (Hofman, 2015). Hoppman, (2015), also assert that, it is not acceptable to deny a customer a chance to cost effective dispute resolution process (arbitration) by banks, knowing well that the amount involved in dispute is too small for the client to face court action.

\section{Methodology}

The paper is based on qualitative approach using some set of unstructured interviews. The unit of analysis (Miles and Huberman, 1994) are staff of Jaiz Islamic bank, as individuals defining the social reality or a phenomenon to be researched. Purposeful sampling technique is used (Patton, 1987); and (Merriam, 1998), by selecting one senior staff from each of some main branches, with the assistance of one of the managers to get their consent, covering 10 branches.

The interviews were conducted in the bank premises, between the periods of June and September 2016, covering primarily the major branches of Jaiz Islamic bank in northern Nigeria. Audio recordings were made for each interview, the following questions were asked:

1. How do you identify your customers' dissatisfaction and likelihood of dispute?

2. When misunderstanding occurs, what is your first action to control the situation?

3. When a customer laid down his complaints and grievances, what do you do first?

4. Who do you involve in resolving conflicts with your customers?

5. At what stage of dispute resolution process do you involve Sharia'h board's consideration?

6. How do you see involving third party in dispute resolution?

7. At what stage of dispute resolution process do you involve third party's intervention?

8. How do you see involving court litigation in resolving conflict?

Collected interview responses were systematically reduced to simplified coded sentences, using Nvivo software and displayed in an organised comprehensive information to enable drawing a meaningful conclusion (Miles, Huberman, \& Saldana, 2013); Guba, (1978) and Patton, (1987) in data management and analysis process, which consist of developing themes in the form of main themes and sub-themes categorization. 


\section{Analysis and discussion of findings}

The main theme of the interview analysis are the informant's preferred ways of resolving disputes. The subthemes, include use of mediation, arbitration, and court litigation to resolve disputes. The following are the discussion on the main themes and sub-themes which emerged from the data analysis gathered from the interviews:

\begin{tabular}{|l|l|l|l|l|l|l|l|}
\hline & \multicolumn{4}{|l|}{ Mediation } & \multicolumn{4}{l|}{ Arbitration } & Litigation & \\
\hline & Mushawarah & Sulh & Mufti & Tahkeem & Mazalim & A-Qaadi & Out of court \\
\hline Number of Informants & 6 & 4 & 7 & 3 & 1 & 2 & 7 \\
\hline
\end{tabular}

Table 1. Category of responses for each dispute resolution process

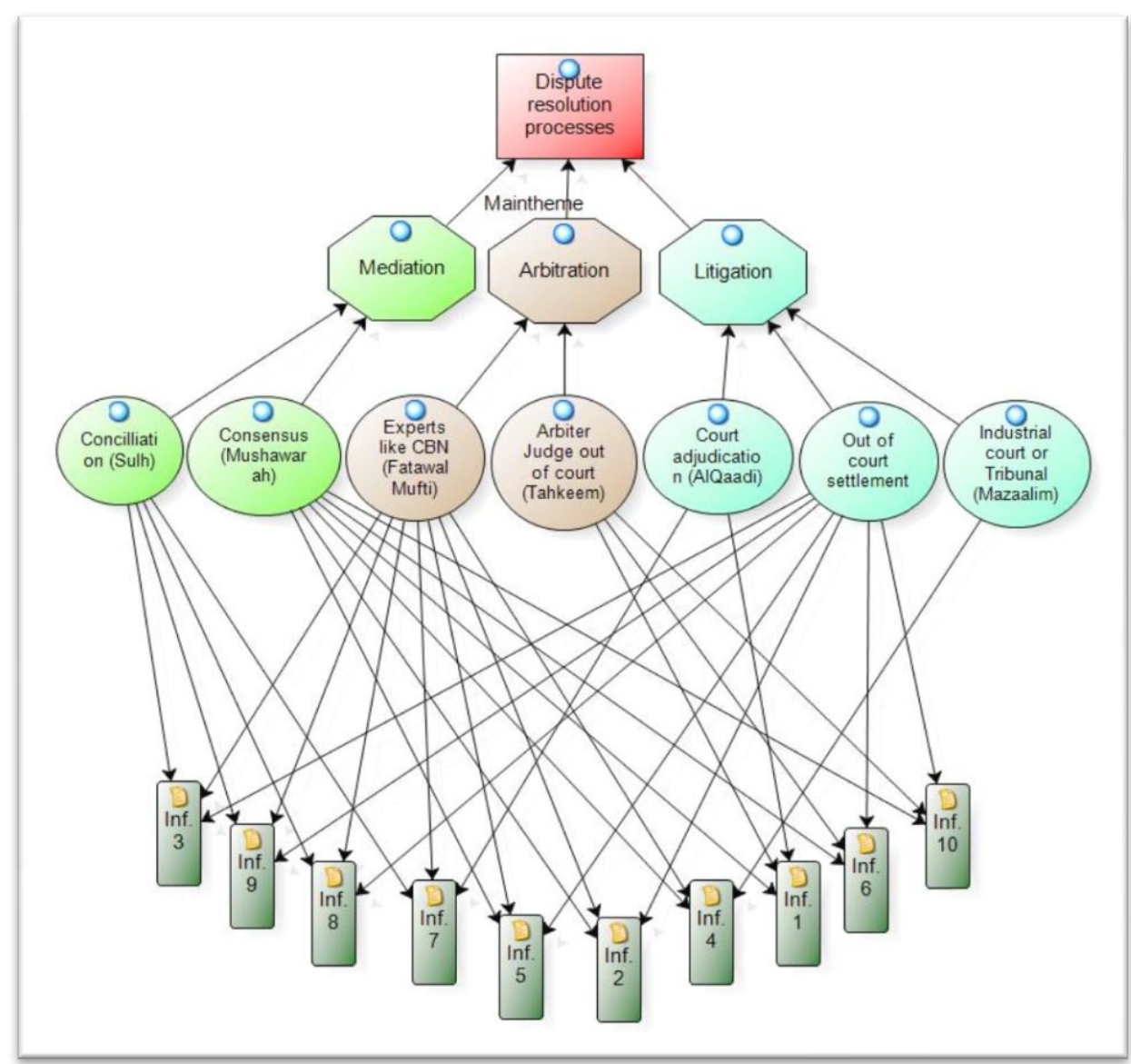

Figure 1. Jaiz bank managers' opinion on choice of dispute resolution process

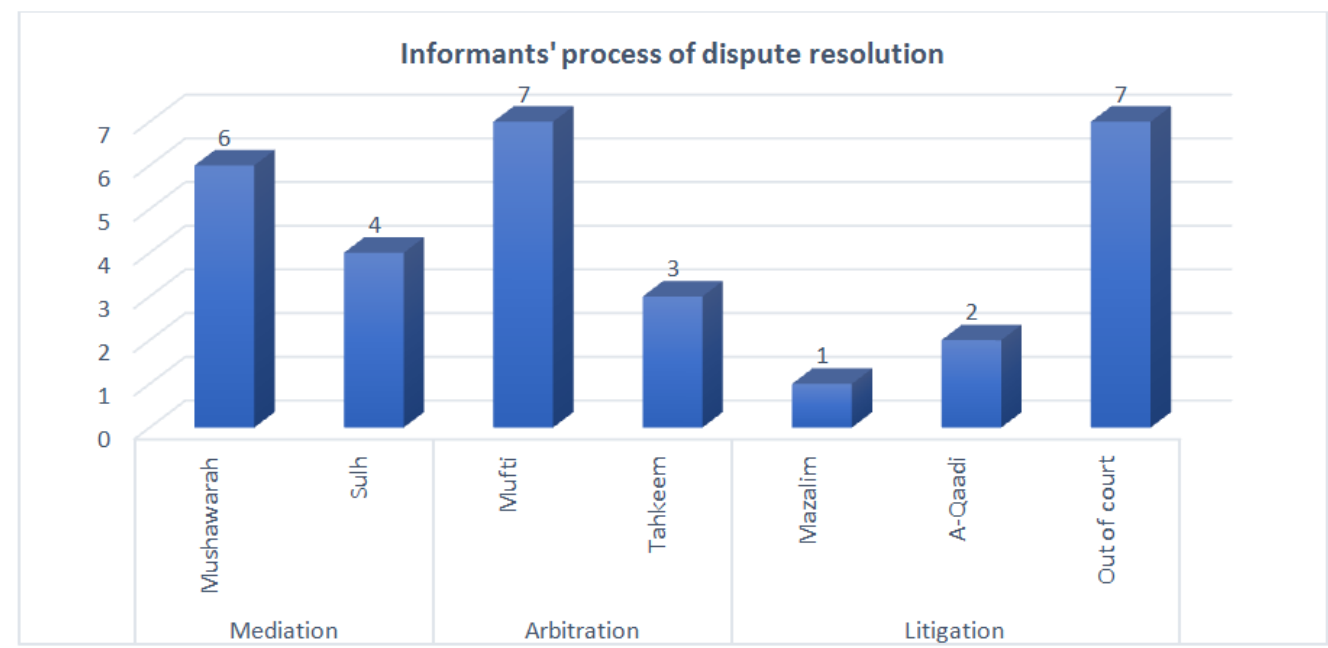

Figure 2. Informants, opinion in each stage of dispute resolution process 
Informants consider mediation as a best and internalised process of effectively settling unclear issues through Opening-up faults of both sides of the disputants for clear deliberations. This is done bank branch management, by hearing the story version of all the disputants (customer and account officer) at the same time for openness. Managers prefer settling issues by conciliation than allowing the case to reach the attention of Shari'ah committee, who supposed to give a fair hearing and judgement to both sides, without biasness. The mediation process at branch level is to ensure and witness clear objectivity by giving a customer chance to express his dissatisfaction (if any), rather than allowing him to go outside the bank to seek redress. Majority of informants prefer settling disputes by conciliation than Sulh at shari'ah committee level, because, customer's confidence on his account officer may be affected.

If use of mediation by either conciliation or consensus was not possible in achieving dispute resolution, managers prefer intervention of financial experts like consumer protection department of central bank of Nigeria $(\mathrm{CBN})$ or any Islamic finance expert than taking the case to an arbiter judge for out of court settlement. Finally, informants disagree with any form of court litigation to settle dispute, rather, they prefer any form of out of court settlement over court litigation. Their opposition to court litigation they assert, was due to the legal system of Nigerian courts, which gives supremacy to conventional courts over Shari'ah courts.

\section{Recommendations}

It can be deduced from the above discussants that; If conflict is about to occur, Islamic bankers are expected to control the situation by fair and ethical concerns through sacrifice, conciliation, and consensus during mediation process. If still, the disagreement escalates to a serious dispute, Islamic bankers should adopt an arbitration process through out of court settlements by Islamic scholars and or CBN.

In either mediation or arbitration process, managers should request both sides of disputants to compromise scores and ensure both parties are satisfied. They ensure reference to Shari'ah (Qur'an and Hadith) in giving verdict, as an internal judgement, to ensure objectivity and religiosity, to enable customer perceive justice in the settlement process.

It is also appropriate during mediation process, to engage and compare the conventional rules of doing business in the country, since customer may be referring to conventional banking practice. It is also appropriate to revisit the previous terms and agreements and compare it to the business convention of the country as well. Lastly, managers should always look forward to the most cost effective and convenient method of arbitration to avoid any party being exposed to additional expenses, and clearly inform the disputant customer the positive and negative implications of going to court.

\section{References}

[1]. Abdul Hak, N., \& Khan, H. A. (2013, August). The Application of Sulh in Resolving Community Disputes. 1st World Congress on Integration and Islamisation of Acquired Human Knowledge (FWCII-2013), Kuala Lumpur.

[2]. Al-Duri, Q. R. (2002). 'Aqd al-taḥkìm fì al-fiqh al-Islami wa-al-Qānūn al-wậ 'ī. Oman: Dār al-Furqān.

[3]. AL-Ghazali, At-Tibr Al-Masbuq Fi Al-Nasihah Al-Muluk vol 1, maktabah al-syamilah Al-Jabali, N. A. (2006). Al-Tahkīm fi alqawānīn al-Arabiyyah: Dirāsah muqāranah fì al-fiqh al-Islāmī wa-al-anzimah al-waḍ 'iyyah. Alexandria: Al-Maktab al-Jāmi'alHadīth.

[4]. Al-Khassaf, A. U. (1978). Ādāb al-Qāḍ̂̀. (F. Ziyadeh, Ed.) Cairo: American University in Cairo.

[5]. Bello, K. B., Suleiman, J. B. A., \& Danjuma, I. (2012). Perspectives on Consumerism and Consumer Protection Act in Nigeria. Perspectives, 4(10).

[6]. Fenn, P., Lowe, D., \& Speck, C. (1997). Conflict and dispute in construction. Construction Management and Economics, 15, 513518 .

[7]. Gerber, P. (2007). Dispute avoidance procedures ("DAPs") - The changing face of construction dispute management. International Construction Law Review, 18(1), 122-129.

[8]. Haidar, A. (1925). Durar al-hukkām fì sharh majallat al-ahkām (Vol. 1). Haifa: Abbasid Press.

[9]. Hofmann, N. (2015). The Role of ADR Institutions: Mere Secretariat or Supervisory Body- Lessons Learned from Institutional Arbitration. The Role of Consumer ADR in the Administration of Justice: New Trends in Access to Justice under EU Directive 2013/11 (pp 103- 114). Sellier European Law Publishers.

[10]. Kerwin, S., Jordan, J. S., \& Turner, B. A. (2015). Organizational justice and conflict: Do perceptions of fairness influence disagreement? Sport Management Review, 18(3), 384-395.

[11]. Lande, J., \& Benner, P. W. (2016). How Businesses Use Planned Early Dispute Resolution. Alternatives to the High Cost of Litigation, 34(4), 49-57.

[12]. Lukonga, I. (2015). Islamic finance, consumer protection, and financial stability. IMF working paper 15/107

[13]. Miles, M. B., Huberman, A. M., \& Saldana, J. (2013). Qualitative data analysis: A methods sourcebook. SAGE Publications, Incorporated.

[14]. Oseni, U. A. (2009). Dispute resolution in Islamic banking and finance: current trends and future perspectives. Available at SSRN 1461895 .

[15]. Oseni, U. A. (2012). Sharī 'ah Court-annexed ADR: The Need for Effective Dispute Management in Waqf, Hibah and Wasiyyah Cases in Malaysia.

[16]. Oseni, U. A. (2015). Dispute management in Islamic financial services and products: A maqāṣid-based analysis. Intellectual Discourse, 23.

[17]. Oseni, U. A. (2015). Shari 'ah court-annexed dispute resolution of three commonwealth countries - a literature review, International Journal of Conflict Management, Vol. 26 Iss 2 pp. 214 -238 
[18]. Oseni, U. A., \& Ahmad, A. U. F. (2015). Dispute resolution in Islamic finance: A case analysis of Malaysia. Ethics, Governance and Regulation in Islamic Finance, 125.

[19]. Oseni, U. A., Adeyemi, A. A., \& Mohd Zain, N. R. (2015). Customers' perceptions on the dispute resolution clauses in Islamic finance contracts in Malaysia. In Federation of Business Disciplines: Southwest Finance Association Annual Conference.

[20]. Rashid, S. K. (2004). Alternative dispute resolution in the context of Islamic law. The Vindobona Journal of International Commercial Law and Arbitration, 8(1), 95-118.

[21]. Sajoo, A. B. (2014). Islam, the shari'ah and alternative dispute resolution: Mechanisms for legal redress in the Muslim community, by Mohamed Keshavjee. Oxford Journal of Law and Religion, 3(3), 530-532.

[22]. Sambo, A. O., \& Kadouf, H. A. (2014). A judicial review of political questions under Islamic law. Intellectual Discourse, 22(1), 33-52.

[23]. Sturner, M. (2015). ADR and Adjudication by State Courts: Competitors or Complements? In M. Sturner, F.G. Inchausti \& R. Caponi (Eds.), The Role of Consumer ADR in the Administration of Justice: New Trends in Access to Justice under EU Directive 2013/11 (pp 11- 30). Sellier European Law Publishers.

[24]. Szalai, I. (2013). Correcting a Flaw in the Arbitration Fairness Act. Journal of Dispute Resolution (2), 271 - 300.

[25]. Thompson, R. M., Vorster, M. C., \& Groton, J. P. (2000). Innovations to Manage Disputes: DRB and NEC. Journal of Management in Engineering, 16(5), 51-59.

[26]. Wilson, T. (2015). Setting Boundaries Rather than Imposing Bans: Is it Possible to Regulate Consumer Arbitration Clauses to Achieve Fairness for Consumers? Griffith University Law School Research Paper, (15-04).

[27]. Zahraa, M., \& Hak, N. A. (2006). Tahkim (Arbitration) in Islamic Law within the Context of Family Disputes. Arab Law Quarterly, 20(1), 2-42. 